\title{
Checklist for the Description of Incommensurate Modulated Crystal Structures. Report of the International Union of Crystallography Commission on Aperiodic Crystals
}

\author{
G. Chapuis, M. Farkas-Jahnke, J. M. Pérez-Mato, M. Senechal, W. Steurer, \\ C. Janot, D. Pandey and A. Yamamoto
}

Acta Cryst. (1997). A53, 95-100

Copyright (C) International Union of Crystallography

Author(s) of this paper may load this reprint on their own web site or institutional repository provided that this cover page is retained. Republication of this article or its storage in electronic databases other than as specified above is not permitted without prior permission in writing from the IUCr.

For further information see http://journals.iucr.org/services/authorrights.html

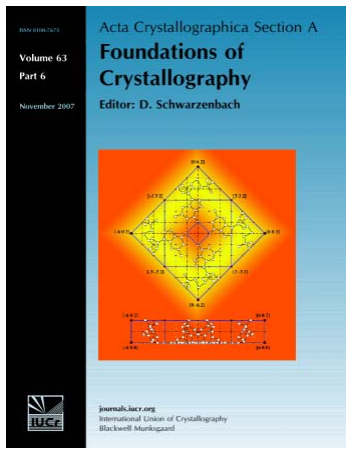

Acta Crystallographica Section A: Foundations of Crystallography covers theoretical and fundamental aspects of the structure of matter. The journal is the prime forum for research in diffraction physics and the theory of crystallographic structure determination by diffraction methods using X-rays, neutrons and electrons. The structures include periodic and aperiodic crystals, and non-periodic disordered materials, and the corresponding Bragg, satellite and diffuse scattering, thermal motion and symmetry aspects. Spatial resolutions range from the subatomic domain in charge-density studies to nanodimensional imperfections such as dislocations and twin walls. The chemistry encompasses metals, alloys, and inorganic, organic and biological materials. Structure prediction and properties such as the theory of phase transformations are also covered.

Crystallography Journals Online is available from journals.iucr.org 
Acta Cryst. (1997). A53, 95-100

\title{
Checklist for the Description of Incommensurate Modulated Crystal Structures Report of the International Union of Crystallography Commission on Aperiodic Crystals $\dagger$
}

\author{
G. Chapuis (Chairman), ${ }^{a *}$ M. Farkas-JahnKe, ${ }^{b}$ J. M. PÉrez-Mato,${ }^{c}$ M. Senechal,${ }^{d}$ W. Steurer,${ }^{e}$ C. JANOt ${ }^{f}$ \\ D. PANDEY ${ }^{g}$ AND A. YAMAMOTO ${ }^{h}$ \\ ${ }^{a}$ Institut de Cristallographie, Université de Lausanne, BSP Dorigny, 1015 Lausanne, Switzerland, ${ }^{b}$ Research \\ Institute for Technical Physics, Hungarian Academy of Sciences, PO Box 76, 1325 Budapest, Hungary, \\ ${ }^{c}$ Departamento de Fisica de la Materia Condensada, Facultad de Ciencias, Universidad del Pais Vasco, Apartado \\ 644, 48080 Bilbao, Spain, ${ }^{d}$ Department of Mathematics, Smith College, Northempton, MA 01043, USA, ${ }^{e}$ Institut \\ für Kristallographie und Petrographie, ETH-Zentrum, 8092 Zurich, Switzerland, ${ }^{f}$ Institut Laue-Langevin, 156 \\ Centre de Tri, Avenue des Martyrs, 38042 Grenoble CEDEX, France, ${ }^{8}$ School of Material Science and Technology, \\ Banaras Hindu University, Varanasi 221 005, India, and ${ }^{h}$ National Institute for Research in Inorganic Materials, \\ Sakura-mura, Niihari-gun, Ibaraki 305, Japan.E-mail: gervais.chapuis@ic.unil.ch
}

(Received 4 June 1993; accepted 8 August 1996)

\begin{abstract}
One of the terms of reference published in 1992 (Acta Cryst. A48, 922-946) in the report of the (at that time) Ad Interim Commission on Aperiodic Crystals was 'to co-operate with other Commissions of the IUCr in establishing adequate guidelines and standards for articles to be published in IUCr journals reporting structural investigations of aperiodic crystals and theoretical investigations of aperiodic patterns'. It was soon recognized by the Commission that the establishment of a checklist for the publication of incommensu-
\end{abstract}

$\dagger$ Final checklist accepted on 15 January 1996 by the Commission on Aperiodic Crystals, on 1 September 1994 by the Executive Committee and on 25 November 1994 by the Commission on Journals. rately modulated structures was perhaps the most urgent task. One of the first attempts to address the problem of publishing incommensurate structures was presented during a discussion organized in 1991 in Leikeitio, Spain, in a workshop dedicated to methods of structural analysis of modulated structures and quasicrystals. Since this meeting, the work of the Commission progressed interactively by numerous exchanges on the occasions of international meetings and mostly by electronic correspondence. The Checklist was accepted in 1994 by the Executive Committee of the IUCr. The opinion of the Commission on Journals was also requested and, following the comments of its members, the Checklist has been completed with an example of an incommensurate crystal structure illustrating each specific item that is required in the Checklist.
This list specifies the information to be given in papers reporting analyses of incommensurate modulated structures. In general, nomenclature should follow the suggestions given in International Tables for Crystallography (1992), Vol. C, pp. 797-847. Dordrecht: Kluwer Academic Publishers.

\begin{tabular}{|l|}
\hline Crystal data \\
\hline Chemical formula. \\
\hline Formula weight. \\
\hline Source of material. \\
\hline Crystal shape and size. \\
\hline $\begin{array}{l}\text { If observed, mention the existence of crystal faces associated to } \\
\text { incommensurate modulation vectors. }\end{array}$ \\
\hline
\end{tabular}

In this column, an example of an incommensurate structure is presented in order to illustrate the corresponding items required by the checklist. The structural data are taken from Acta Cryst. (1994), B50, 333-343.

$\left(\mathrm{C}_{3} \mathrm{H}_{7} \mathrm{NH}_{3}\right)_{2} \mathrm{MnCl}_{4}$

316.98

Slow evaporation at room temperature of a stoichiometric aqueous solution of $n-\mathrm{C}_{3} \mathrm{H}_{7} \mathrm{NH}_{3} \mathrm{Cl}$ (Sigma) and $\mathrm{MnCl}_{2}$ (Merck, >98\%)

Platelet, $\{001\}$ pinacoid $[0.064(4) \mathrm{mm}$ thick], $\{111\}$ orthorhombic dipyramid [base: $0.618(4) \times 0.612(4) \mathrm{mm}$ ]

The crystals were grown at room temperature at which the structure is commensurate
(C) 1997 International Union of Crystallography Printed in Great Britain - all rights reserved 


\begin{tabular}{|c|c|}
\hline Crystal system of the incommensurate structure. & Orthorhombic \\
\hline $\begin{array}{l}\text { Superspace group [International Tables for Crystallography (1992). } \\
\text { Vol. C, pp. } 797-847 \text { (Dordrecht: Kluwer Academic Publishers); de } \\
\text { Wolff, Janner \& Janssen (1981). Acta Cryst. A37, 625-636] or } \\
\text { equivalent description of the symmetry of the incommensurate } \\
\text { modulated structure. }\end{array}$ & $\operatorname{Abma}(a 01) 000$ (No. 64.3) \\
\hline $\begin{array}{l}\text { Set of generators of the superspace group in explicit form (choice of } \\
\text { origin and setting). In the case of an alternative symmetry } \\
\text { description, minimal mathematical information sufficient for } \\
\text { deriving the implied symmetry restrictions on the atomic } \\
\text { modulations. }\end{array}$ & 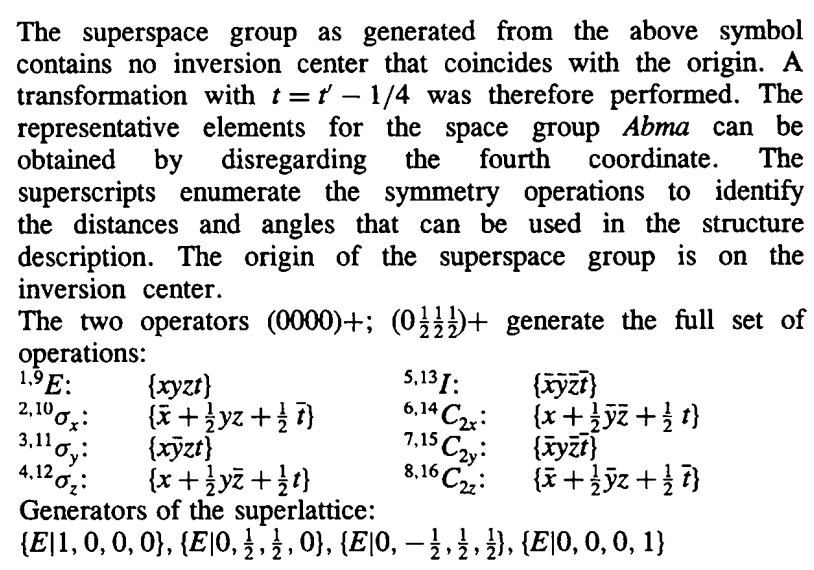 \\
\hline $\begin{array}{l}\text { Diffraction symmetry (Laue symmetry, systematic absences) and } \\
\text { possible superspace group(s) compatible with it. }\end{array}$ & $\begin{array}{ll}\text { hklm: } & k+l+m=2 n \\
h k 0 m: & h=2 n \\
0 k l 0: & k=2 n\end{array}$ \\
\hline $\begin{array}{l}\text { Unit-cell dimensions (cell parameters and volume) of the average } \\
\text { lattice deduced from main reflections; number and } \theta \text { range of main } \\
\text { reflections used for this measurement. }\end{array}$ & $\begin{array}{l}\text { Lattice parameters }(\dot{\mathrm{A}}): a=7.414(2), b=7.289(2), c=26.803(7) \\
V\left(\dot{\mathrm{A}}^{3}\right): 1448(1) \\
\text { Number of main reflections: } 1846 ;[>3 \sigma(I)]: 1331 \\
(\sin \theta / \lambda)_{\max }\left(\dot{\mathrm{A}}^{-1}\right): \quad 0.53 \text { for }|m|=0,1 \\
\\
0.37 \text { for }|m|=2\end{array}$ \\
\hline $\begin{array}{l}\text { Independent modulation wave vector(s) } \mathbf{q}_{i} \text { (with standard } \\
\text { deviations) with which diffraction vectors are indexed in the } \\
\text { form } h \mathbf{a}^{*}+k \mathbf{b}^{*}+l \mathbf{c}^{*}+\sum m_{i} \mathbf{q}_{i}\left(\mathbf{a}^{*}, \mathbf{b}^{*}, \mathbf{c}^{*}: \text { unit-cell parameters of }\right. \\
\text { the average lattice; } h, k, l, m_{i}: \text { integers). For commensurately } \\
\text { modulated structures described in the superspace formalism, the } \\
\text { rational components of the modulation vector(s) should be } \\
\text { given. }\end{array}$ & $\mathbf{q}_{i}=0.176(1) \mathbf{a}^{*}$ \\
\hline$Z$ & 4 \\
\hline Measured and calculated densities $D_{m}$ and $D_{x}$ & $D_{x}=1.462 \mathrm{Mg} \mathrm{m}^{-3}$ \\
\hline Radiation and wavelength. & $\lambda_{\mathrm{Cu}}=1.54184(\dot{\mathrm{A}})$ \\
\hline Linear absorption coefficient. & $\mu(\mathrm{Cu} K \alpha)=140.1 \mathrm{~cm}^{-1}$ \\
\hline$F(000)$ & 652 \\
\hline \multicolumn{2}{|l|}{ Data collection } \\
\hline Diffractometer used. & Syntex $P 2_{1}$ \\
\hline Temperature of measurement. & $\begin{array}{l}351(5), \quad 365(5) \mathrm{K} \text { for the first, second crystal, respectively. } \\
\text { Temperature stability better than } \pm 0.3 \mathrm{~K}\end{array}$ \\
\hline Method to measure diffraction data. & $2 \theta-\omega$ scans, graphite monochromator \\
\hline
\end{tabular}




\begin{tabular}{|c|c|}
\hline $\begin{array}{l}\text { Method of determining the independent modulation wave vector(s) } \\
\mathbf{q}_{i} \text {. }\end{array}$ & $\begin{array}{l}\text { Obtained by averaging the fractional parts of index } h \text { of ten } \\
\text { accurately centered first-order satellites at } 2 \theta \simeq 50^{\circ}\end{array}$ \\
\hline $\begin{array}{l}\text { Temperature variation of the modulation wave vector(s), if } \\
\text { measured. }\end{array}$ & Reported in Solid State Commun. 45, 1089-1092 \\
\hline $\begin{array}{l}\text { Method of measuring satellite reflections }\left(m_{i} \neq 0\right) \text {. Comparison } \\
\text { between intensity profiles of satellite reflections and main reflections } \\
\left(m_{i}=0\right) \text {. }\end{array}$ & $\begin{array}{l}\text { Same as for main reflections } \\
\text { FWHM }\left(^{\circ}, h k l m\right): 0.60(4000), 0.52(0400), 0.48(0080), 0.59 \\
(0,4,13, \overline{1}), 0.52(118 \overline{1})\end{array}$ \\
\hline $\begin{array}{l}\text { Absorption correction applied (maximum and minimum } \\
\text { transmission values). }\end{array}$ & $\begin{array}{l}0.638-0.053 \\
\text { (analytical correction method applied) }\end{array}$ \\
\hline $\begin{array}{l}\text { For each reflection class } m\left(=\sum\left|m_{i}\right|\right) \text { : number of measured } \\
\text { reflections; range of } h, k, l ; \sin \theta / \lambda \text { range; internal } R \text { value from } \\
\text { merging equivalent reflections. } \\
\text { Maximum value of } \theta \text {. } \\
\text { Number of independent reflections, total and for each reflection } \\
\text { class. } \\
\text { Criterion for recognizing unobserved reflections. } \\
\text { Number of observed reflections, total and for each reflection class. }\end{array}$ & $\begin{array}{lrrrc} & |m|=0 & |m|=1 & |m|=2 & \text { Total } \\
R_{\text {int }}\left(2 \theta: 3-70^{\circ}, \text { full sphere }\right) & & & & \\
\text { with absorption correction } & 0.063 & 0.067 & 0.083 & 0.064 \\
\text { without absorption correction } & 0.137 & 0.186 & 0.134 & 0.144 \\
\text { Number of reflections } & 1846 & 3820 & 897 & 6563 \\
\text { [> } 3 \sigma(I)] & 1331 & 2126 & 127 & 3584 \\
\text { Independent reflections } & 524 & 1072 & 292 & 1888 \\
\quad[>3 \sigma(I)] & 369 & 627 & 60 & 1056\end{array}$ \\
\hline $\begin{array}{l}\text { Standard reffections chosen (at least one reflection for each } \\
\text { measured reflection class should be included) and their intensity } \\
\text { variation during the measurement. }\end{array}$ & $\begin{array}{l}1190 ; 0080 ; 4400 ; 0011 ; 2 \overline{2} \overline{1} \overline{1} ; 041 \overline{1} \\
\text { Loss of intensity: } \sim 30 \% \text { within } 216 \mathrm{~h} \\
\text { Equal decay for }|m|=0,1\end{array}$ \\
\hline $\begin{array}{l}\text { Thermal history of the sample(s). Temperature stability during the } \\
\text { measurement. }\end{array}$ & $\begin{array}{l}\text { Freshly grown crystals at room temperature were heated once to the } \\
\text { temperature of measurement. The temperature was estimated from } \\
\text { the } T \text { dependence of the modulation vector } q(T)\end{array}$ \\
\hline Characteristics of diffuse scattering phenomena if any. & - \\
\hline \multicolumn{2}{|l|}{ Refinement } \\
\hline $\begin{array}{l}\text { Brief outline of the refinement method used. Computer programs } \\
\text { employed. }\end{array}$ & $\begin{array}{l}\text { The average structure was solved first, followed by the } \\
\text { incommensurate structure refinement. SHELX [Sheldrick (1978), } \\
\text { SHELXTL. An Integrated System for Solving, Refining and } \\
\text { Displaying Crystal Structures from Diffraction Data. University of } \\
\text { Göttingen, Federal Republic of Germany] and MSR [Paciorek } \\
\text { (1991). Methods of Structural Analysis of Modulated Structures and } \\
\text { Quasicrystals, edited by J. M. Pérez-Mato, F. J. Zúñiga \& G. } \\
\text { Madariaga, pp. 268-279. Singapore: World Scientific] were used } \\
\text { for the refinements of the structure }\end{array}$ \\
\hline $\begin{array}{l}\text { Structure-factor calculation: analytical expression for the structure } \\
\text { factor and all the modulation functions used. This information } \\
\text { should be sufficient to reproduce the modulations of all the } \\
\text { symmetry-equivalent atoms. Method and accuracy of numerical } \\
\text { integration, if any. }\end{array}$ & $\begin{array}{l}\text { Structure-factor expressions taken from Paciorek \& Chapuis [Acta } \\
\text { Cryst. (1994), A50, 194-203]. Additional modulated functions are } \\
\text { derived in the original paper } \\
\text { Gaussian integrations with } 32 \text { divisions }\end{array}$ \\
\hline $\begin{array}{l}\text { Type(s) of modulation. Parameters used to describe the individual } \\
\text { atomic modulation functions (including the modulation of thermal } \\
\text { parameters, if any). Mention all tested models. }\end{array}$ & $\begin{array}{l}u_{i}^{\mu}(t)=\sum_{n>0}\left[c_{i, n}^{\mu} \cos (2 \pi n t)+s_{i, n}^{\mu} \sin (2 \pi n t)\right] \text { with } t=\mathbf{q}\left(\mathbf{n}+\mathbf{r}^{\mu}\right) \bmod 1, \\
\beta_{i j}^{\mu}(t)=\beta_{i j .2}^{\mu} \cos \left(4 \pi t+\chi_{i j .2}^{\mu}\right) \\
t \text { is the internal coordinate ranging between } 0 \text { and } 1 ; i \text { refers to the } \\
\text { direction and } \mathbf{r}^{\mu} \text { is the average position of atom } \mu \text { within the unit } \\
\text { cell } \mathbf{n} \text { of the average structure }\end{array}$ \\
\hline $\begin{array}{l}\text { Symmetry restrictions and/or constraints on the structure } \\
\text { parameters, if any. }\end{array}$ & $\begin{array}{l}\text { Symmetry restrictions on coordinates, thermal displacement } \\
\text { parameters and modulation parameters for the atoms on special } \\
\text { sites. The parentheses indicate those Debye-Waller-factor (DWF) } \\
\text { modulation parameters that are set to zero according to the phason/ } \\
\text { amplitudon parametrization proposed by Pérez-Mato et al. [Solid } \\
\text { State Commun. (1991), 78, 33-37] }\end{array}$ \\
\hline
\end{tabular}




\begin{tabular}{|c|c|}
\hline & 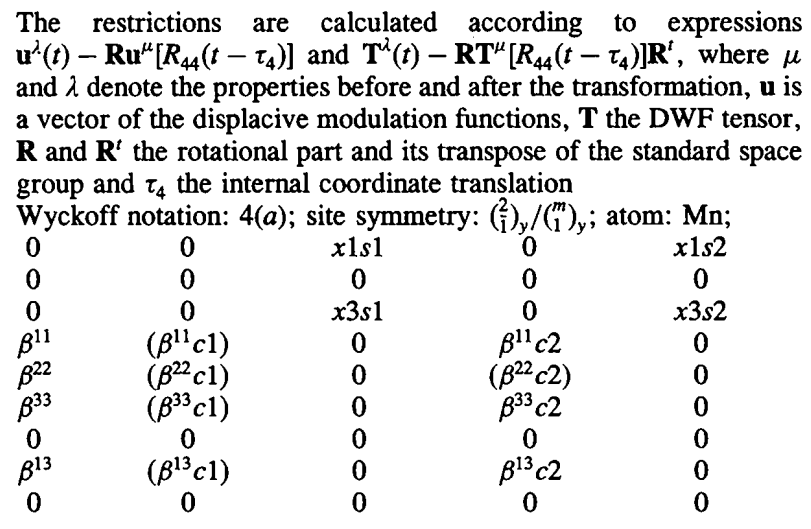 \\
\hline Source of scattering factors. & $\begin{array}{l}\text { Scattering factors for neutral atoms taken from International Tables } \\
\text { for X-ray Crystallography (1974), Vol. IV (Birmingham: Kynoch } \\
\text { Press) }\end{array}$ \\
\hline Starting structural model. Parameters refined. & $\begin{array}{l}\text { As starting parameters, the coordinates of the } \delta \text { phase at room } \\
\text { temperature [Peterson \& Willet }(1972) \text {. J. Chem. Phys. 56, 1879- } \\
1882] \text { were used. An improved model with C1 and C2 on general } \\
\text { positions } 16(a) \text { in } A b m a \text { yielded a significantly better agreement. N } \\
\text { and C3 were refined on the mirror plane } 8(f)\end{array}$ \\
\hline Use of $F, F^{2}$ or $I$ in the refinement. & Refinement based on $F$ \\
\hline $\begin{array}{l}\text { Constraints in the refinement process if any; restraints on } \\
\text { stereochemical quantities or other parameters and their weights, if } \\
\text { any. }\end{array}$ & $\begin{array}{l}\text { Bond distances and angles constraints for } H \text { atoms in the average } \\
\text { structure } \\
\text { Constraints on first-order harmonics of the temperature-factor } \\
\text { modulation }\end{array}$ \\
\hline $\begin{array}{l}\text { Number of reflections used in the refinement; number of refined } \\
\text { parameters. }\end{array}$ & $\begin{array}{lll}\text { Model } 5 a & 1058 \text { reflections } & 80 \text { parameters } \\
\text { Model } 5 b & 1888 \text { reflections } & 80 \text { parameters }\end{array}$ \\
\hline Method of locating and refining $\mathrm{H}$ atoms. & $\begin{array}{l}\text { From stereochemical considerations. The modulation parameters } \\
\text { were approximately constrained to the values of the bonded atom }\end{array}$ \\
\hline $\begin{array}{l}\text { Weighting scheme in the refinement: definition of } w \text { for reflections } \\
\text { and, in the case of the refinement restraints, for the pseudo- } \\
\text { observations introduced. }\end{array}$ & $1 / \sigma^{2}(F)$ \\
\hline $\begin{array}{l}\text { Overall, and for each reflection class, final values of } R=\sum\left(|| F_{o} \mid-\right. \\
\left|F_{c}\right|\left|/ \sum\right| F_{o} \mid, w R=\left[\sum w\left(Y_{o}-Y_{c}\right)^{2} / \sum w Y_{o}^{2}\right]^{1 / 2} \text {, where } Y_{o} \text { and } Y_{c} \\
\text { are the observed and calculated coefficients specified above } \\
\left(|F|, F^{2} \text { or } I\right) \text {. } \\
\text { Final value of } \Sigma=\left[\sum w\left(Y_{o}-Y_{c}\right)^{2} /(m-n)\right]^{1 / 2} \text { for all reflections. } \\
\text { Ratio of maximum least-squares shift to error in final refinement } \\
\text { cycle. }\end{array}$ & 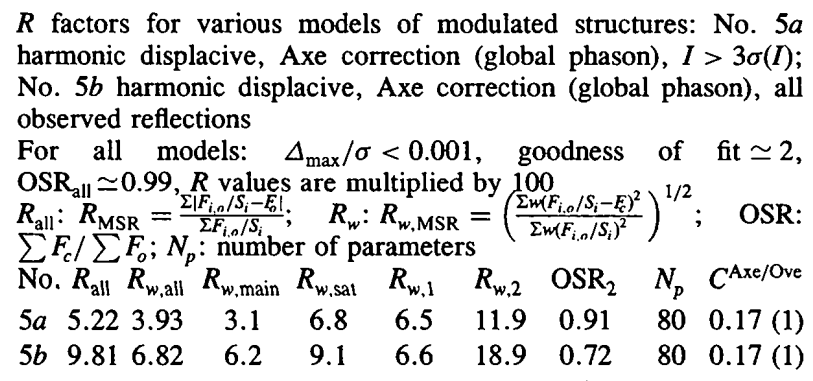 \\
\hline $\begin{array}{l}\text { In the case of refinement restraints, an analog } w R^{\prime} \text { and } S^{\prime} \text { for the } \\
\text { pseudo-observations is recommended. }\end{array}$ & - \\
\hline $\begin{array}{l}\text { Maximum and minimum of } \Delta \rho \text { in final superspace difference } \\
\text { Fourier synthesis. }\end{array}$ & Not available \\
\hline $\begin{array}{l}\text { Extinction correction method (if applied). Primary- and secondary- } \\
\text { extinction values. }\end{array}$ & $\begin{array}{l}\text { Isotropic } \quad \text { extinction } \quad F_{c}^{\mathrm{corr}}=F_{c} /\left(1+10^{-5} C_{\mathrm{ext}} F_{c}^{2} / \sin \theta\right)^{1 / 4}, \\
C_{\mathrm{ext}}=2.6(2)\end{array}$ \\
\hline
\end{tabular}




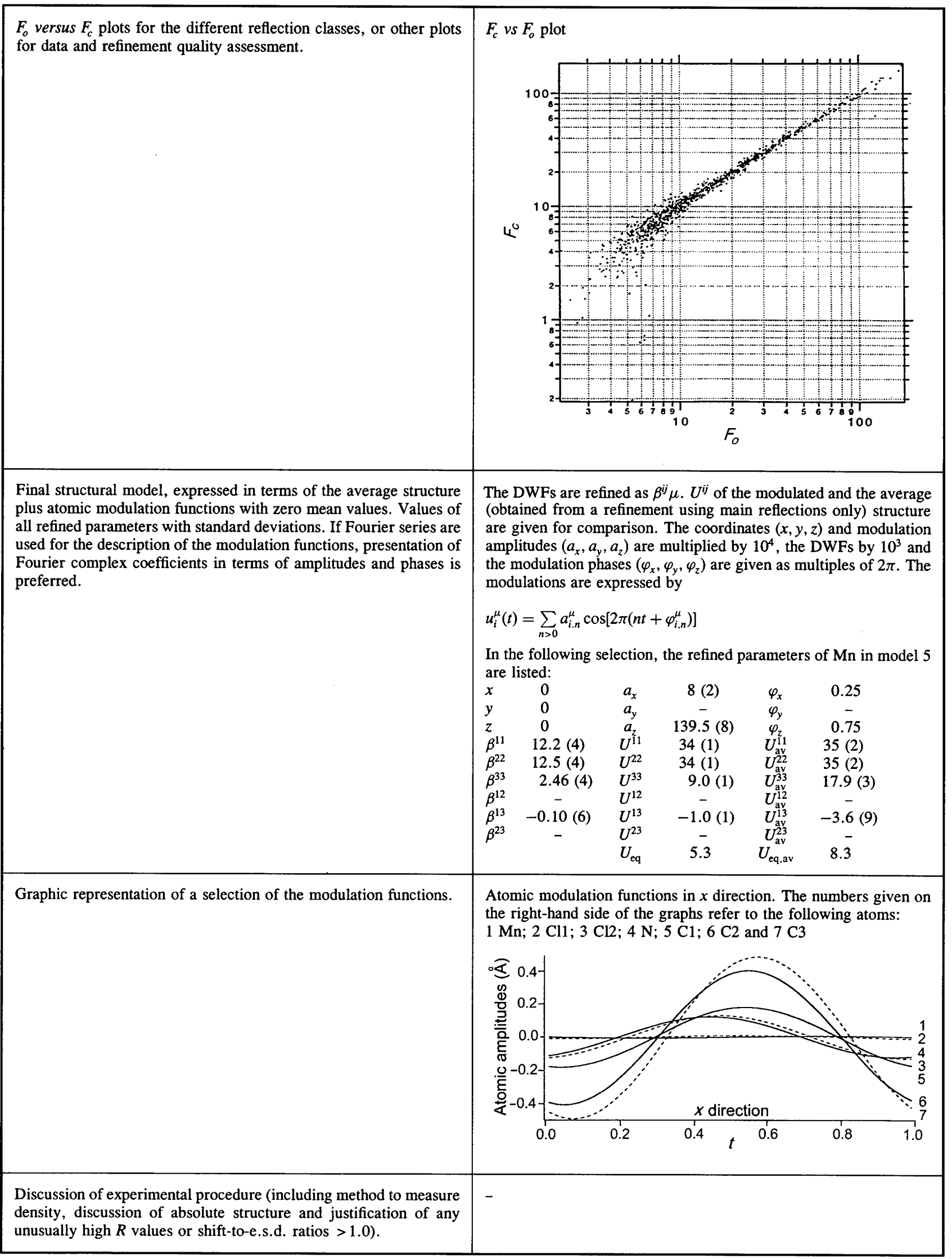




\begin{tabular}{|c|c|}
\hline Selected geometrical data & \\
\hline $\begin{array}{l}\text { Average, minimum and maximum interatomic distances and other } \\
\text { pertinent geometrical parameters. }\end{array}$ & 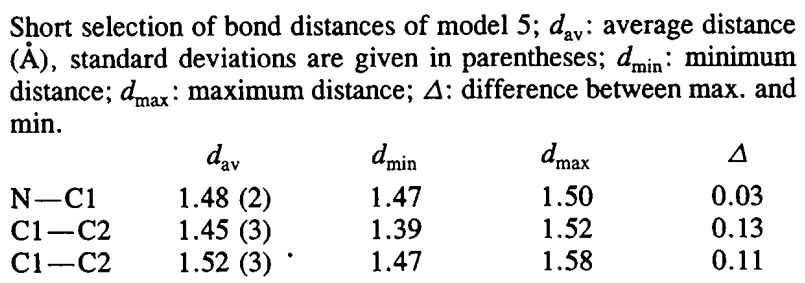 \\
\hline $\begin{array}{l}\text { Graphical representation of a selection of pertinent geometrical } \\
\text { parameters along the internal coordinate(s). }\end{array}$ & $\begin{array}{l}\text { Atomic modulation functions of } \mathrm{Cl} 2 \text {. For this atom, the positional } \\
\text { parameters } x \text { and } z \text { are modulated (first harmonic) as well as the } \\
\text { Debye-Waller terms } U^{11}, U^{33} \text { and } U^{13} \text { (second harmonic). For six } \\
\text { values of } t \text { (internal coordinate), ORTEP plots of } \mathrm{Cl} 2 \text { are given } \\
\text { (projection parallel to b) showing the rotation of the thermal } \\
\text { ellipsoid as a function of } t \text { due to Debye-Waller-factor modulation }\end{array}$ \\
\hline $\begin{array}{l}\text { If possible, comparison of the modulation with those in related } \\
\text { compounds. }\end{array}$ & $\begin{array}{l}\text { See Doudin \& Chapuis [Acta Cryst. (1990), B46, 175-180, } 180- \\
\text { 186] }\end{array}$ \\
\hline $\begin{array}{l}\text { If possible, comparison with other phases, commensurate and } \\
\text { incommensurate of the same compound: structure and space-group } \\
\text { relations, atomic modulations. }\end{array}$ & Mentioned in the Discussion \\
\hline $\begin{array}{l}\text { In the material to be deposited, the list of structure factors should } \\
\text { include their } N \text {-dimensional indexing }\left(h, k, l, m_{1}, \ldots, m_{i}, \ldots\right)\end{array}$ & $\begin{array}{lllrccc}h & k & l & m & F_{o} & \Delta F\left(=F_{o}-F_{c}\right) & \sigma(F) \\
0 & 0 & 1 & -1 & 15.21 & 0.27 & 0.27 \\
0 & 0 & 2 & 0 & 120.53 & 9.73 & 2.02\end{array}$ \\
\hline
\end{tabular}

We thank Dr W. Paciorek and M. Meyer of the University of Lausanne for their criticisms and constructive remarks during the elaboration of the Checklist. 